\title{
Pathogenic and Molecular Characterization of Fusarium oxysporum f.sp. ciceri Causing Chickpea
Wilt through ISSR Markers
}

\author{
Pravin D.Gajbhe ${ }^{1}$, Madhuri Katkar ${ }^{2}$, S.S.Mane ${ }^{3}$, P.V.Jadhav ${ }^{4}$ \\ ${ }^{1,2,3}$ Department of Plant Pathology, Dr. Panjabarao Deshmukh Krishi Vidyapeeth, Akola, Maharashtra, India \\ ${ }^{4}$ Biotechnology centre, Dr. Panjabarao Deshmukh Krishi Vidyapeeth, Akola, Maharashtra, India
}

\begin{abstract}
In the present investigation the pathogenic and genetic variability was assayed, amongst the seven isolates of Fusarium oxysporum f.sp. ciceri (Foc) collected from different agro-climatic zones of Maharashtra State, India. The isolates of Fusarium oxysporum f.sp.ciceri were confirmed by SCAR marker which yielded $1.5 \mathrm{KD}$ band. The pathogenicity of each isolate was confirmed using the wilt susceptible chickpea genotype JG-62. On the basis of pathogenic ability the isolates were grouped as highly pathogenic (FOC-2, FOC-5, FOC-6), strongly pathogenic (FOC-1,FOC-3) and moderately pathogenic (FOC-4,FOC7). Eight Inter Simple Sequence Repeats primers (ISSRs) were used to determine the genetic variability in seven isolates Fusarium oxysporum f.sp. ciceri. The seven primers produced 80 scorable bands. Off 80 bands, 73 bands were polymorphic and average level of polymorphism was 91.25 per cent. In UPGMA analysis, Foc-1 (Wardha) was found to have higher value of similarity coefficient (0.8375) whereas Foc-2 (Lonar) was found to have lower value of similarity coefficient (0.4625). The isolates of Fusarium oxysporum f.sp.ciceri were grouped into two major clusters. First group, cluster-A includes isolates belonging to Wardha, Washim and Lonar. Second group, cluster-B includes Nashik, Ahmednagar, Rahuri and Pune. It shows that Foc-1 (Wardha) have higher value of similarity coefficient with Foc-3 (Washim) whereas Foc-2 (Lonar) have lower value of similarity coefficient with Foc-5 (Ahmednagar).The similarity matrix indicated that seven isolates of Fusarium oxysporum f.sp.ciceri exhibited in between 46-84 per cent similarity coefficient.
\end{abstract}

Keywords-Fusarium oxysporum f.sp. ciceri, ISSR Markers, Pathogenic variation.

\section{INTRODUCTION}

Chickpea (Cicer arietinum L.) is one of the most important pulse crop grown worldwide. It is reported to be infested by more than 52 pathogen (Nene et al., 1984). The losses due to Fusarium oxysporum f. sp. ciceri had been reported to the tune of 10 to $100 \%$ Grewal et al. (1974). Being soil borne in nature use of host plants resistance is the most practical and economical approach for management of Fusarium wilt of chickpea (Haware, 1990). The pathogen is monophyletic in nature, complete one life cycle in a year, but the occurrence of races in the form of variability had been demonstrated by Haware and Nene (1982).The studies the pathogenic variability revealed that the chickpea wilt pathogen Fusarium oxysporum f.sp. ciceri had four distinct physiological races in India (Haware and Nene, 1982). Hence, it becomes necessary to ascertain the molecular variability amongst the isolates of Fusarium oxysporum f.sp. ciceri in order to have the specific breeding programme, it is necessary to determine the genetic variability among the isolates of Fusarium oxysporum f.sp.ciceri at molecular level, so as the breeding programme for race specific wilt resistant varieties could be initiated. The present investigation will helps to understand the genetic variability among the isolates of Fusarium oxysporum f.sp. ciceri in Maharashtra, which in turn will be useful for its exploitation for regional race specific breeding programme for developing wilt resistance variety. The various workers had demonstrated that molecular markers viz. RAPD (Bayraktar and Dollar 2007) ISSR ( Akram et.al.2014, Borrego-Benjumea et al. 2014) ITSRFLP (Arpita Das et.al.2012, Gayatri Gurjar et al. 2009), AFLP (Mamta Sharma et al. 2009) RAPD and ISSR (Madhuri Katkar et.al 2015) were useful in characterizing genetic variation in a wide range of organisms. In the present investigation ISSR molecular markers were used to analyze the genetic variability of Fusarium oxysporum f.sp. ciceri isolates collected from different agro-climatic zones of Maharashtra, India. 
II.

\section{MATERIALS AND METHODS}

Fungal isolates

A total seven isolates of $F$. oxysporum $\mathrm{f}$. sp. ciceris (FOC) were isolated from wilt-infected chickpea plants from different agro-climatic zones of Maharashtra (Table-1) were designated as FOC-1 (Wardha), FOC-2 (Lonar), FOC3 (Washim), FOC-4 (Nashik), FOC-5 (Ahmednagar), FOC6 (Rahuri) and FOC-7 (Pune). Isolations were made from the wilted plants on potato dextrose agar (PDA) medium. The fungus was identified according to the identification keys of $F$. oxysporum f.sp.ciceri.

Molecular Characterization of $\boldsymbol{F}$. oxysporum f.sp.ciceri. The Fusarium oxysporum f.sp. ciceri specific Sequence Characterized Amplified Region (SCAR) primer pair Foc012 f-GGCGTTTCGCAGCCTTACAATGAAG and Foc012 r-GACTCCTTTTTCCCGAGGTAGGTCAGAT were used for the confirmation of the isolates (Jimenez Gasco and Jimenez Diaz, 2003)

\section{Pathogenicity test}

The pathogenicity test of isolates of $F$. oxysporum f.sp. ciceri isolated from the different agro-climatic zones of the Maharashtra state, India; were tested by using susceptible cultivar JG-62.The seven isolates of $F$. oxysporum f.sp. ciceri were purified by hyphal tip method were mass multiplied separately on sand maize meal medium. The soil for experiment taken was autoclaved for 3 day consequently at $30 \mathrm{lbs}$ pressure for 30 minutes. The mass multiplied inoculum was mixed with the soil in 1:10 proportion and filled in the presterilized pots. Five seeds of susceptible chickpea cultivar JG-62 were sown in pots each isolate in 3 replications. The per cent emergence and post-emergence mortality at 30 DAS was recorded and total mortality was calculated. The seedlings maintained in sterilized soil without inoculums were served as control. The pathogenicity test was confirmed by proving Koch's Postulate and pathogens were confirmed as Fusarium oxysporum f.sp ciceri.

Grouping of Fusarium oxysporum f. sp. ciceri isolates

The isolates of $F$. oxysporum f. sp. ciceri were tentatively divided in five groups based on their pathogenic ability on cv. JG-62 given as per Paul et.al. (2001).

\section{Category}

1. Nonpathogenic (NPI)

Per cent wilt/root rots

2. Weakly pathogenic (WPI)

3. Moderately pathogenic (MPI)

4. Strongly pathogenic (SPI)

5. Highly pathogenic (HPI)

$0 \%$
$1-20 \%$
$21-50 \%$
$51-70 \%$
$>70 \%$

\section{Genomic DNA extraction}

The pure culture of seven isolates of Fusarium oxysporum f.sp ciceri were grown on Potato Dextrose Broth (200 g peeled potato, $20 \mathrm{~g}$ dextrose, $1000 \mathrm{ml}$ distilled water) for 7 days $\left(27 \pm{ }^{\circ} \mathrm{C}\right)$. The mycelial mat for each isolates was harvested. The DNA was extracted following CTAB method of DNA extraction by Murray and Thompson (1980) with little modifications. The DNA obtained after extraction was confirmed by running it on $0.8 \%$ agarose gel containing ethidium bromide at $0.5 \mathrm{mg} / \mathrm{ml}$ in a horizontal gel electrophoresis system. $2 \mu \mathrm{l}$ of genomic DNA of each isolate $+3 \mu$ l loading dye $+5 \mu$ l sterile water loaded in each well. After completion of $5 \mathrm{~cm}$ run, the gel was observed under UV light and the DNA yield and quality was confirmed

\section{ISSR Analysis}

The eight ISSR primers supplied by "BIOSERVE" were used to amplify the DNA. The DNA amplification was carried out in a thermal cycler (Eppendorf, Germany) with the conditions as described by Kelly et al. (1994) as follows: one cycle of initial denaturation at $94^{\circ} \mathrm{C}$ for 10 minutes, followed by 35 cycles of denaturation at $94^{\circ} \mathrm{C}$ for $45 \mathrm{sec}$, annealing at $50-54^{\circ} \mathrm{C}$ (as per primers) for $45 \mathrm{sec}$ and primer extension at $72^{\circ} \mathrm{C}$ for 2 minutes. A final extension at $72^{\circ} \mathrm{C}$ for 10 minutes was carried out at the end of the cycles. Amplifications was performed in a total volume of $25 \mu \mathrm{l}$ of reaction, containing $10 \mathrm{mM}$ of Tris- $\mathrm{HCl}\left(\mathrm{P}^{\mathrm{H}} 8.8\right)$, $50 \mathrm{mM}$ of $\mathrm{KCl}, 2.5 \mathrm{mM}$ of $\mathrm{Mgcl}_{2}, 0.24 \mu \mathrm{M}$ of primer, $0.2 \mathrm{mM}$ of dNTPs, and $1 \mathrm{U}$ of Taq polymerase. The eight ISSR primers with di- and tri- nucleotide repeats were analyzed. The annealing temperatures were adjusted as per $\mathrm{G}+\mathrm{C}$ content of the primers.

\section{Electrophoresis of ISSR-PCR product:}

The ISSR analysis was carried out in vertical gel electrophoresis. The PCR products were separated eletrophoretically in 1.5 percent agarose gel. The ISSR-PCR product $(7 \mu \mathrm{l})$ with $3 \mu \mathrm{l}$ loading dye in each well was loaded along with $1 \mathrm{~kb}$ DNA ladder $(5 \mu \mathrm{l})$ with $3 \mu \mathrm{l}$ loading dye in the first well. The gel was run for at $80 \mathrm{~V}$.

\section{Gel documentation and Data analysis:}

The gel images were captured and visualizaed in gel documentation system (Biorad). The data was scored as the presence (1) or absence (0) of individual band for each isolates in PCR-ISSR analysis of each isolate of Fusarium oxysporum f.sp. ciceri. The data was used to generate similarity coefficient using simple matching coefficient based on ISSR bands pattern. The Dice coefficient between each pair of accessions were then used to construct a 
dendrogram using the Unweighted Pair Group Method with Arithmetic Mean Average (UPGMA).

III.

\section{RESULTS AND DISCUSSION} Molecular characterization of isolates of Fusarium oxysporum f.sp. ciceri:

All the isolates of the races yielded the single $1.5 \mathrm{~kb}$ band (Plate-2 ) with the SCAR marker, hence confirms the culture of Fusarium oxysporum f.sp. ciceri were as per the result of Jimenez Gasco and Jimenez- Diaz (2003).

\section{Pathogenicity and Grouping of isolates}

The results (Table -2 and Table-3) indicates that all the among seven isolates of Fusarium oxysporum f. sp. ciceri, all proved to be pathogenic to susceptible cultivar JG62.Isolate from FOC-2 was highly virulent(100\%) and caused wilting and death of the seedlings in 20-22 days. Whereas remaining isolates viz. FOC-1(66.66\%), FOC$3(60.00 \%)$, FOC-4(50.00\%), FOC-5(92.85\%), FOC$6(84.61 \%)$ and FOC-7(42.00\%) respectively. On the basis of the reactions the seven isolates $F$. oxysporum f.sp. ciceri FOC-4,FOC-7 has been classified as Moderately Pathogenic (21-50\%),FOC-1,FOC-3 as Strongly Pathogenic (51-70\%) and FOC-2,FOC-5,FOC-6 as Highly Pathogenic (> $70 \%$ ). On the basis of pathogenic ability by Paulkar et al. (2002) reported the virulence of four isolates of $F$. oxysporum f. sp. ciceri under laboratory conditions. Isolate Foc-3 showed $100 \%$ mortality on JG-62 (highly pathogenic), isolates Foc-1 and Foc-4 showed 70 and 90 per cent mortality respectively. Whereas, Foc- 2 isolate showed moderately pathogenic reaction with $60 \%$ mortality. Barhate et al. (2006) reported per cent mortality among these seven isolates three isolates were highly pathogenic (71-100\%), two strongly pathogenic and two were moderately pathogenic.

\section{Molecular Characterization}

The genetic diversity (Table-4 Plate-1and 3) was studied amongst the seven isolates of Fusarium oxysporum f.sp. ciceri using eight ISSR primers. Among them seven primers produced 80 scorable bands. Out of 80 bands, 73 bands were polymorphic and average level of polymorphism was 91.25 per cent. The primer $(\mathrm{GA})_{9} \mathrm{RY}$ amplified maximum 15 bands within the size 408bp13984bp, while primer $(\mathrm{AG})_{8} \mathrm{~T}$ and $(\mathrm{AG})_{8} \mathrm{YT}$ amplified minimum of 9 bands within the size 550bp to $13628 \mathrm{bp}$ and $394 \mathrm{bp}$ to 2766bp respectively. The six ISSR primers $(\mathrm{AG})_{8} \mathrm{~T}$ (13628bp); (ATG) $)_{6}$ (7706bp); (AG) $)_{8} \mathrm{G}$ (712bp); $(\mathrm{AG})_{8} \mathrm{YT} \quad(587 \mathrm{bp}) \quad(\mathrm{CA})_{8} \mathrm{RT} \quad(2675 \mathrm{bp})$ and $(\mathrm{AC})_{8} \mathrm{YT}$ (1384bp),(1210bp) showed 7 monomorphic bands.

Binary similarity matrix for ISSR analysis
On the basis of calculated similarity matrix, the similarity between two genotypes was predicted. The genotypes showing similarity index of " 1 " are presumed to be 100 per cent similar while that of " 0 " are 100 per cent genetically dissimilar. In the dendrogram (Table $1 \& 5$, Fig-1) the similarity matrix indicated that seven isolates of Fusarium oxysporum f.sp. ciceri exhibited in between 46-84 per cent similarity coefficient. It was clear that in cluster $\mathrm{A}$, the three isolates FOC-1 (Wardha) and FOC-2 (Washim) were grouped which showed the $83.75 \%$ similarity,.The isolates FOC -1 (Wardha) and FOC -2 (Washim) falls under the agro-ecological zone viz. Moderate rainfall zone VIII and assured rainfall zone which has the soil $\mathrm{PH}$ ranging from 7 to 7.5 and the soil type Vertisols and Inceptisols. Whereas the isolate FOC -3 (Lonar) showed $46.25 \%$ similarity with FOC -1 (Wardha) and FOC -2 (Washim) falls in cluster A and the variation may be due to high alkaline $\mathrm{pH}$ of soil which had sustained the meteorite impact in the past. In cluster-B, it includes isolates FOC -4 (Nashik), FOC 5(Ahmednagar), FOC -6 (Rahuri, Ahmednagar) and FOC -7 (Pune).From the dendrogram it is cleared that two isolates FOC - 4 (Nashik), FOC -5(Ahmednagar) exhibits 66\% similarity level, both the agro-ecological zones are adjacent to each other with moderately alkaline soils with $\mathrm{pH}$ ranging from 7.4 to 8.4. The FOC -6 (Rahuri, Ahmednagar) isolates showed the $61 \%$ similarities with the rest of isolates, falls in the scarcity zone, where as FOC -7 (Pune) falls in the Western Maharashtra Plain Zone which as the lateritic to black soil has $\mathrm{pH} 6$ to 7 which are poor in the potash and phosphorus has the $58 \%$ similarities with rest of all the isolates. Borrego-Benjumea et al. (2014) studied genetic variation in several soil borne Fusarium spp. caused Fusarium crown and root rot of asparagus. Ninety-three Fusarium isolates, obtained from plant and soil samples collected from commercial asparagus fields in southwestern Ontario, were identified as Fusarium oxysporum (65.5\%), $F$. proliferatum $(18.3 \%), F$. solani $(6.4 \%), F$. acuminatum $(6.4 \%)$, and $F$. redolens $(3.2 \%)$ based on morphological or cultural characteristics and polymerase chain reaction (PCR) analysis with species-specific primers. The inter simple-sequence repeat (ISSR) PCR analysis of the field isolates revealed considerable variability among the isolates belonging to different Fusarium spp. Akram et al. (2014) studied the genetic variation amongst ten different isolates of Fusarium oxysporum f. sp. lycopersici causing wilt in tomato. These isolates were collected from infected tomato plants from different tomato fields. Genetic finger printing of all $F$. oxysporum $\mathrm{f}$. sp. lycopersici isolates was performed by using ISSR markers. Dendrogram based on the ISSR 
analysis divided all $F$. oxysporum f. sp. lycopersici isolates in two major groups.

Thus it clearly indicates that the genesis of soil, $\mathrm{pH}$, presence of types of nutrients and elements in the soil plays important roles in evolution of the soil borne plant pathogen their variation, multiplication adoption and survival that had been clear from the present investigation.

\section{ACKNOWLEDGEMENT}

The author are thankful to the Head Department of Plant Pathology ,Post Graduate Institute, and In charge ,Biotechnology Centre, Dr.PDKV,Akola (M.S.) for providing necessary facilities for conducting the research work.

\section{REFERENCES}

[1] Akram, T. Anjum, A. Ahmad .2014. Basal susceptibility of tomato varieties against different isolates of Fusarium oxysporum f.sp. lycopersici. International Journal of Agriculture and Biology; 2014. 16(1):171-176.

[2] Arpita Das, M. Venkataramana, S. Chandranayaka, H.S. Murali And H. V. Batra .2012. Molecular characterization of Fusarium oxysporum f. sp. cubense isolates from banana. Pest Management in Horticultural Ecosystems. 18 (2),171-178

[3] Barhate, B. G., G. N. Dake., B. C. Game and D. N. Padule. 2006. Variability for virulence in Fusarium oxysporum f. sp. ciceri causing wilt of chickpea. Legume Res. 29 (4): 308-310.

[4] Bayraktar, H., F. S. Dolar and S. Maden. 2007. Use of RAPD and ISSR marker in detection of genetic variation and population, structure among Fusarium oxysporum f. sp. ciceris isolates on chickpea in. Turkey J. Phytopathology. 156 (3): 146-54.

[5] Borrego-Benjumea, M.J. Basallote-Ureba, J. M. Melero-Vara, and P. A. Abbasi. 2014. Characterization of Fusarium Isolates from Asparagus Fields in Southwestern Ontario and Influence of Soil Organic Amendments on Fusarium Crown and Root Rot Volume 104, Number 4: Pages 403-415

[6] Grewal. J. S., Mahendra Pal and D. D. Kulshrestha, 1974. Annul Report, Division of Mycology and Plant Pathology, Indian Agricultural Research Institute, New Delhi, 110012
[7] Gurjar, Gayatri, Maneesha Barve, Ashok Giri and Vidya Gupta. 2009. Identification of Indian pathogenic races of Fusarium oxysporum f.sp. ciceris with gene specific, ITS and random markers. Mycologia. 101(4):484-495.

[8] Haware M. P. and Y. L. Nene, 1982. Races of Fusarium oxysporum f.sp. ciceris. Plant Dis 66(9): 809-10

[9] Haware, M.P., 1990. Fusarium wilt and other important diseases of chickpea in the Mediterranean area. Options Mediterraneennes Serie Seminaires. 9 1990: 61-64.

[10] Jimenez-Gasco, M. M., M. G. Milgroom and R. M. Jimenez-Diaz, 2003. Development of a specific Polymerase Chain Reaction -based assay for identification of Fusarium oxysporum $\mathrm{f}$. sp. ciceris and its pathogenic races 0,1A, 5 and 6. The American Phytopathological Society. 93(2): 200-209

[11] Kelly AG, Alcal'a-Jim'enez AR, Bainbridge BW, Heale JB, P'erez-Art'es E and Jim'enez-D'1az RM (1994) Use of genetic fingerprinting and Random Amplified Polymorphic DNA to characterize pathotypes of Fusarium oxysporum f. sp. ciceris infecting chickpea. Phytopathology 84:1293-1298

[12] Mamta Sharma, R. K. Varshney, J. N. Rao, Seetha Kannan, D. Hoisington and S. Pande. 2009. Genetic diversity in Indian isolates of Fusarium oxysporum $\mathrm{f}$. sp. ciceris, chickpea wilt pathogen. African Journal of Biotechnology. 8(6): 1016-1023.

[13] Madhuri Katkar, S.S. Mane and Nivedita Kadam (2015) Molecular characterization races of Fusarium oxysporum f.sp. ciceri using RAPD and ISSR markers. Legume Research 38 ( 2) 246-252

[14]Murray, M.G. and Thompson W.F. 1980. Rapid isolation of high molecular weight DNA. Nucleic Acid Res. 8: 4321-4325.

[15] Nene, Y. L., V. K. Sheila and S.B. Sharma. 1984. Pulse Pathology Progress Report (ICRISAT) 32:2-9.

[16] Paul, Joginder, T. S. Gill and R. S. Singh. 2001. Variability among isolates of Fusarium oxysporum f.sp. ciceri from chickpea roots and rhizosphere. Plant Dis. Res. 16: 116-118.

[17] Paulkar, P.K and Raut, B.T. 2004. Variability among the isolates of Fusarium oxysporum f. sp. ciceri. Journal of Mycology and Plant Pathology. 34 (1): 2023. 
Table.1: Collection of isolates from different agro-climatic zones of Maharashtra State, India

\begin{tabular}{|c|c|c|c|c|}
\hline Sr. & Agro climatic zone & $\begin{array}{l}\text { District of } \\
\text { Collection }\end{array}$ & $\begin{array}{l}\text { Designated } \\
\text { as }\end{array}$ & Soil Type \\
\hline 1. & $\begin{array}{l}\text { Moderate rainfall } \\
\text { zone (zone-VIII) }\end{array}$ & Wardha & FOC-1 & $\begin{array}{l}\text { Black soil derived from basalt rock, Medium to } \\
\text { heavy in texture alkaline to reaction. Low lazing } \\
\text { areas are rich, fertile. }\end{array}$ \\
\hline 2. & $\begin{array}{l}\text { Assured rainfall } \\
\text { zone (zone-VII) }\end{array}$ & $\begin{array}{c}\text { Lonar, Dist. } \\
\text { Buldhana }\end{array}$ & FOC-2 & \multirow{2}{*}{$\begin{array}{c}\text { Soil colour ranges from black to red type Vertisols, } \\
\text { Entisoles, Inceptisols PH 7-7.5 }\end{array}$} \\
\hline 3. & $\begin{array}{l}\text { Assured rainfall } \\
\text { zone (zone-VII) }\end{array}$ & Washim & FOC-3 & \\
\hline 4. & Transition zone-II & Nashik & FOC-4 & $\begin{array}{l}\text { Soil grayish black, Moderately alkaline } 7.4 \text { to } 8.4 \\
\text { lowest layer is murum strata Fair in NPK content, } \\
\text { well drained good for irrigation }\end{array}$ \\
\hline 5. & Scarcity zone & Ahmednagar & FOC-5 & \multirow{2}{*}{$\begin{array}{l}\text { Vertisols with Montmorilonite clay, poor in } \\
\text { nitrogen low to medium in phosphate and well } \\
\text { supplied in potash }\end{array}$} \\
\hline 6. & Scarcity zone & $\begin{array}{l}\text { Ahmednagar } \\
\text { (Rahuri) }\end{array}$ & FOC-6 & \\
\hline 7. & $\begin{array}{c}\text { Western } \\
\text { Maharashtra Plain } \\
\text { zone } \\
\end{array}$ & Pune & FOC-7 & $\begin{array}{l}\text { Soils are reddish brown to black tending to lateritic } \\
\mathrm{Ph}-6 \text { to } 7 \text {, well supplied in Nitrogen and low in } \\
\text { phosphorus and potash. }\end{array}$ \\
\hline
\end{tabular}

Table.2 : Pathogenicity reaction of isolates of Fusarium oxysporum f.sp.ciceri

\begin{tabular}{|c|c|c|c|c|c|c|}
\hline Isolates & $\begin{array}{l}\text { No. of } \\
\text { plants }\end{array}$ & Germination & $\begin{array}{c}\% \\
\text { Germination }\end{array}$ & $\begin{array}{l}\text { Wilted } \\
\text { plants }\end{array}$ & $\begin{array}{c}\% \\
\text { Wilting }\end{array}$ & $\begin{array}{l}\text { Wilting } \\
\text { (DAI) }\end{array}$ \\
\hline FOC-1 & 15 & 12 & 80.00 & 08 & 66.66 & 24 \\
\hline FOC-2 & 15 & 15 & 100.00 & 15 & 100.00 & 22 \\
\hline FOC-3 & 15 & 10 & 66.66 & 06 & 60.00 & 25 \\
\hline FOC-4 & 15 & 14 & 93.33 & 7 & 50 & 25 \\
\hline FOC-5 & 15 & 14 & 93.33 & 13 & 92.85 & 26 \\
\hline FOC-6 & 15 & 13 & 86.66 & 11 & 84.61 & 25 \\
\hline FOC-7 & 15 & 14 & 93.33 & 6 & 42.86 & 22 \\
\hline Control & 15 & 15 & 100.00 & 00 & 00 & 00 \\
\hline
\end{tabular}

Table .3: Grouping of F. oxysporum f.sp. ciceri isolates on the basis of pathogenicity.

\begin{tabular}{|c|c|c|}
\hline Sr. & Group (\% Mortality) & F. oxysporum f.sp.ciceri \\
\hline 1 & Non-Pathogenic $(0 \%)$ & $(0)$ \\
\hline 2 & Weakly Pathogenic $(1-20 \%)$ & $(0)$ \\
\hline 3 & Moderately Pathogenic $(21-50 \%)$ & FOC-4,FOC-7 \\
\hline 4 & Strongly Pathogenic $(51-70 \%)$ & FOC-1,FOC-3 \\
\hline 5 & Highly Pathogenic $(>70 \%)$ & FOC-2,FOC-5,FOC-6 \\
\hline
\end{tabular}


Table.4: The ISSR primers and their polymorphism

\begin{tabular}{|c|c|c|c|c|}
\hline Sr. No. & Primer & Total Bands & Polymorphic bands & $\begin{array}{c}\% \\
\text { Polymorphism }\end{array}$ \\
\hline 1 & $(\mathrm{GA})_{9} \mathrm{RY}$ & 15 & 15 & 100 \\
\hline 2 & $(\mathrm{AG})_{8} \mathrm{~T}$ & 9 & 8 & 98.88 \\
\hline 3 & $(\mathrm{ATG})_{6}$ & 10 & 9 & 91.66 \\
\hline 4 & $(\mathrm{AG})_{8} \mathrm{G}$ & 12 & 11 & 88.88 \\
\hline 5 & $(\mathrm{AG})_{8} \mathrm{YT}$ & 9 & 10 & 90.90 \\
\hline 6 & $(\mathrm{CA})_{8} \mathrm{RT}$ & 11 & 12 & 85.71 \\
\hline 7 & $(\mathrm{AC})_{8} \mathrm{YT}$ & 14 & 73 & 91.25 \\
\hline Total & & 80 & & \\
\hline
\end{tabular}

Table.5: Similarity coefficient for ISSR analysis

\begin{tabular}{|c|c|c|c|c|c|c|}
\hline Foc-1 Wardha & $\begin{array}{c}\text { Foc-2 } \\
\text { Lonar }\end{array}$ & $\begin{array}{c}\text { Foc-3 } \\
\text { Washim }\end{array}$ & $\begin{array}{c}\text { Foc-4 } \\
\text { Nashik }\end{array}$ & Foc-5 Ahmednagar & $\begin{array}{c}\text { Foc-6 } \\
\text { Rahuri }\end{array}$ & $\begin{array}{c}\text { Foc-7 } \\
\text { Pune }\end{array}$ \\
\hline 1.0000 & & & & & & \\
\hline 0.5875 & 1.0000 & & & & & \\
\hline 0.8375 & 0.6750 & 1.0000 & & & & \\
\hline 0.5375 & 0.5000 & 0.6000 & 1.0000 & & & \\
\hline 0.4750 & 0.4625 & 0.4875 & 0.6625 & 1.0000 & 1.0000 & \\
\hline 0.4625 & 0.5500 & 0.4750 & 0.6000 & 0.6125 & 0.5625 & 1.0000 \\
\hline 0.5000 & 0.5125 & 0.5375 & 0.6375 & 0.5250 & & \\
\hline
\end{tabular}

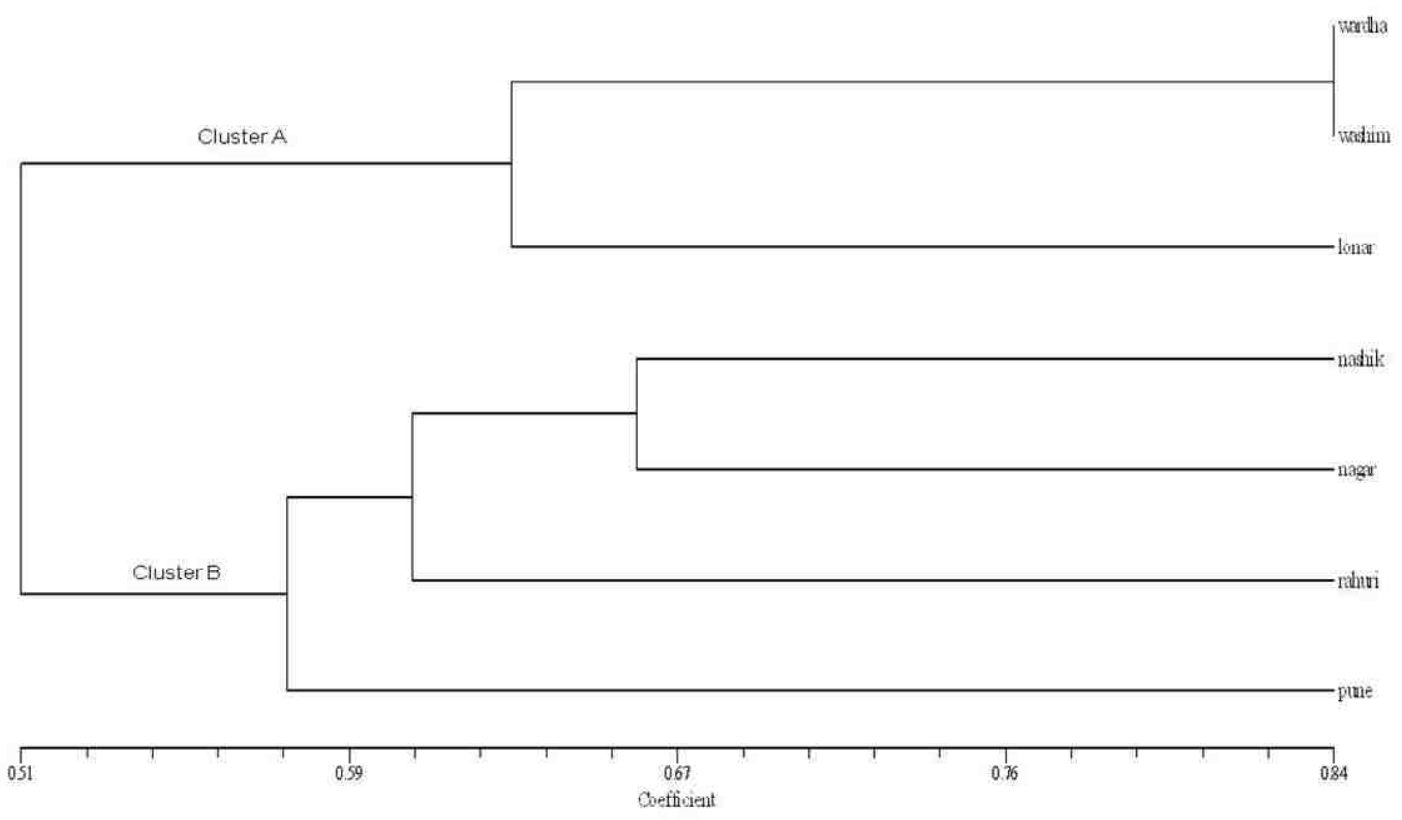

Fig. 1. The ISSR UPGMA dendrogram of seven isolates of $F$ oxysporum $\mathrm{f}$ sp ciceribased on Jaccard's Similarity Coefficient 


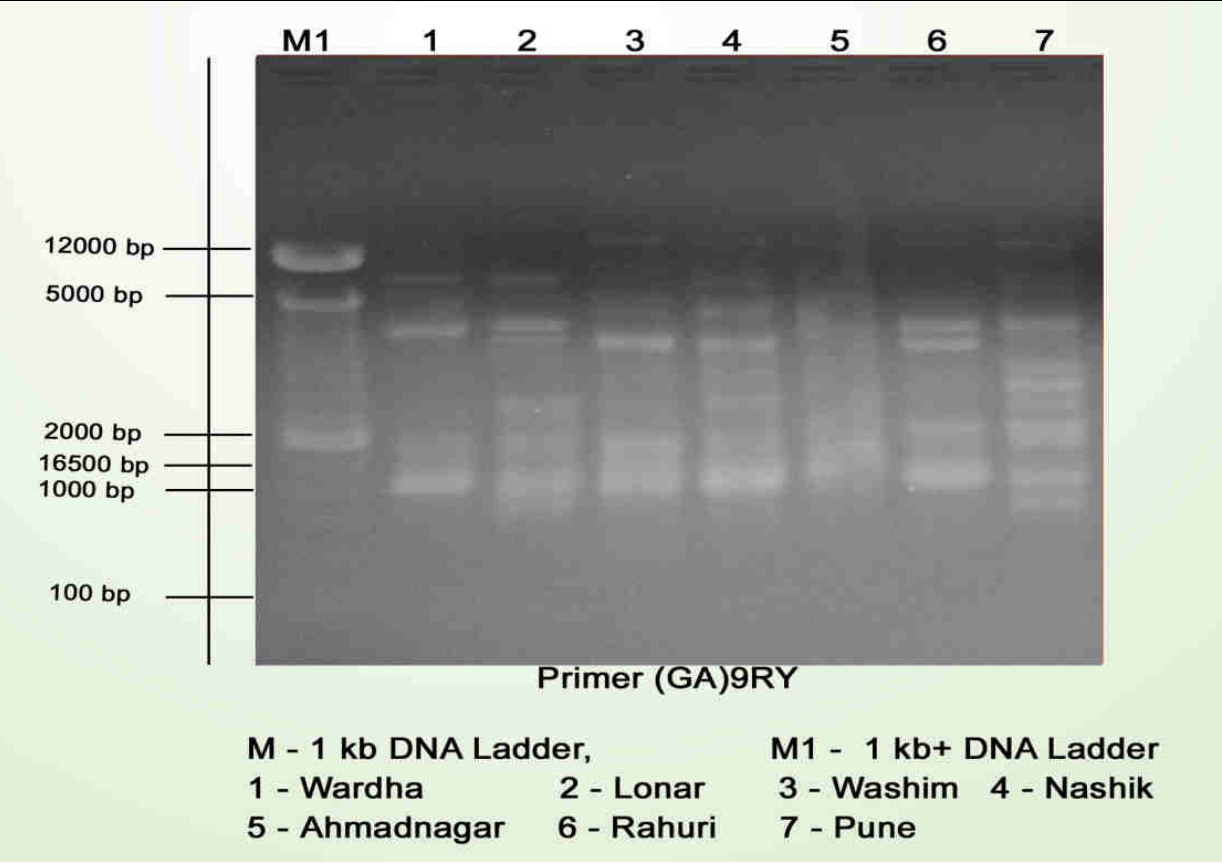

Plate 1: ISSR banding pattern of Primer $(G A)_{9} R Y$

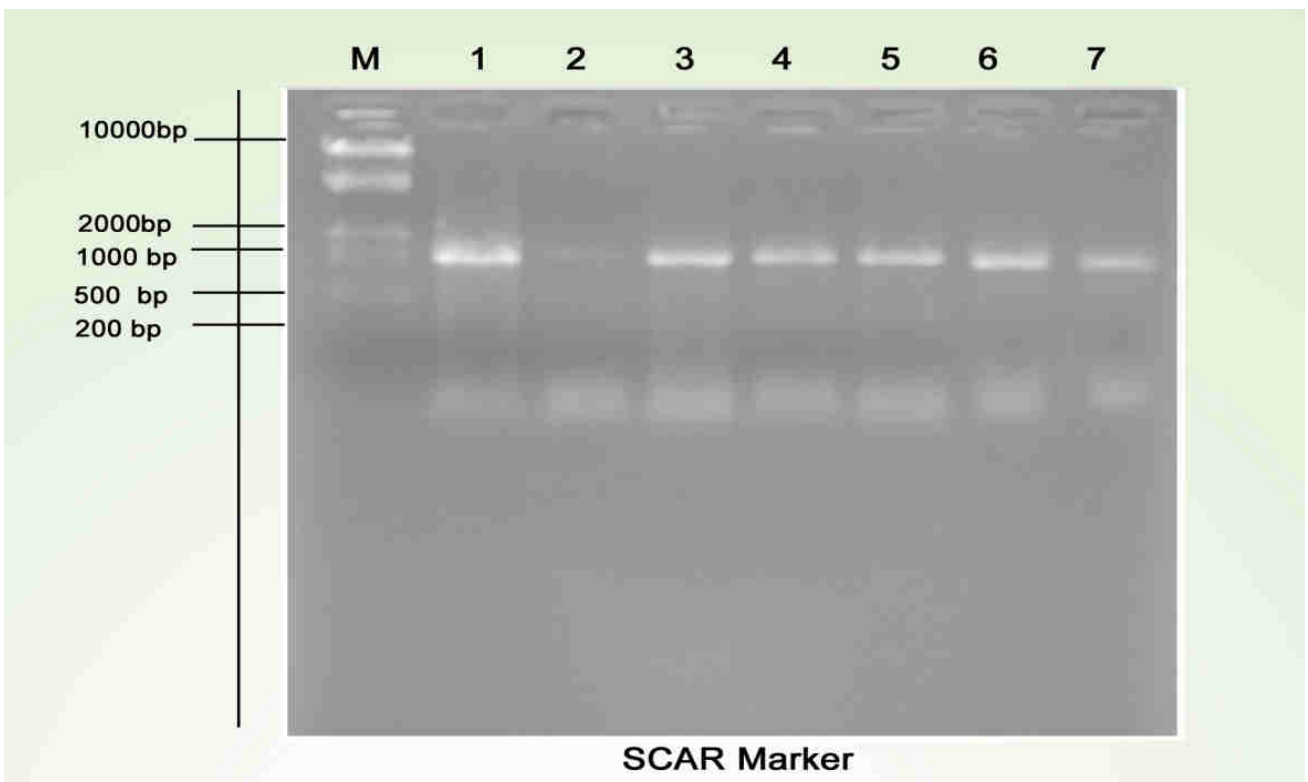

Plate 2 : Molecular confirmation of Fusarium oxysporium f.sp. ciceri showing $1.5 \mathrm{~kb}$ band size with SCAR Marker 


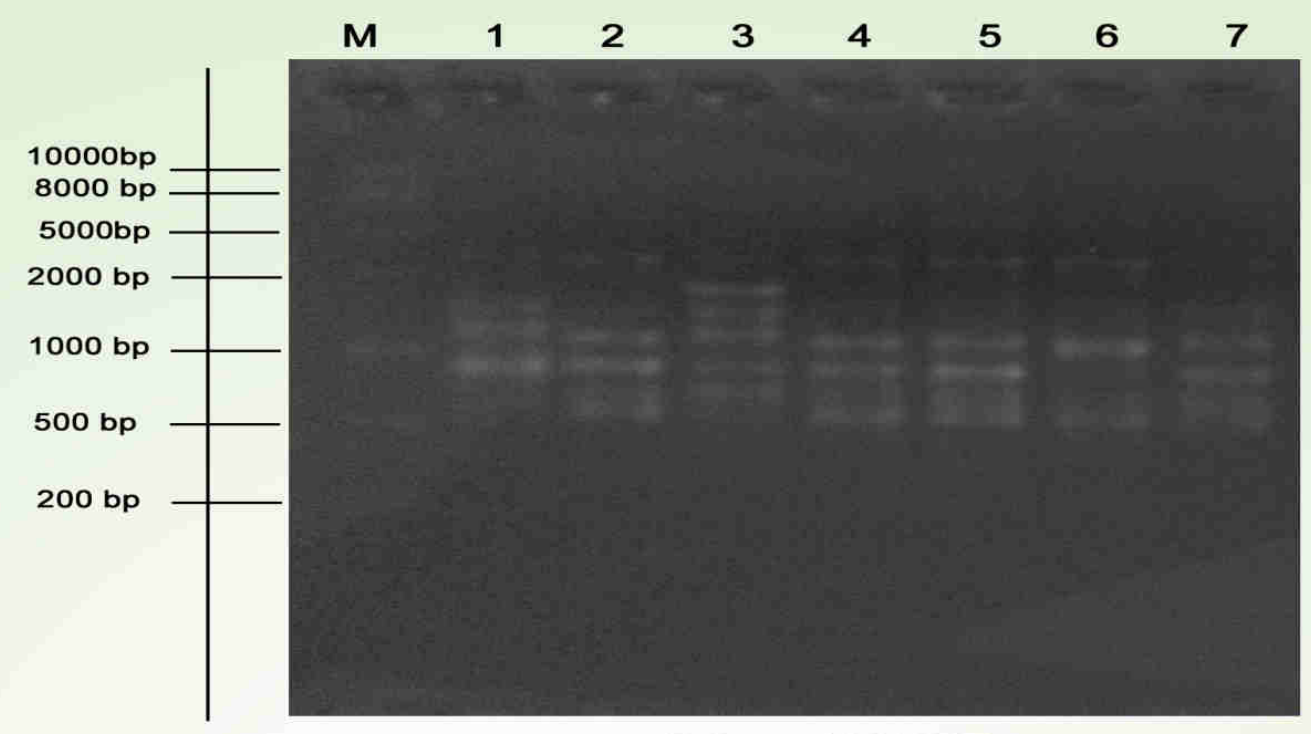

Primer (CA)8RT

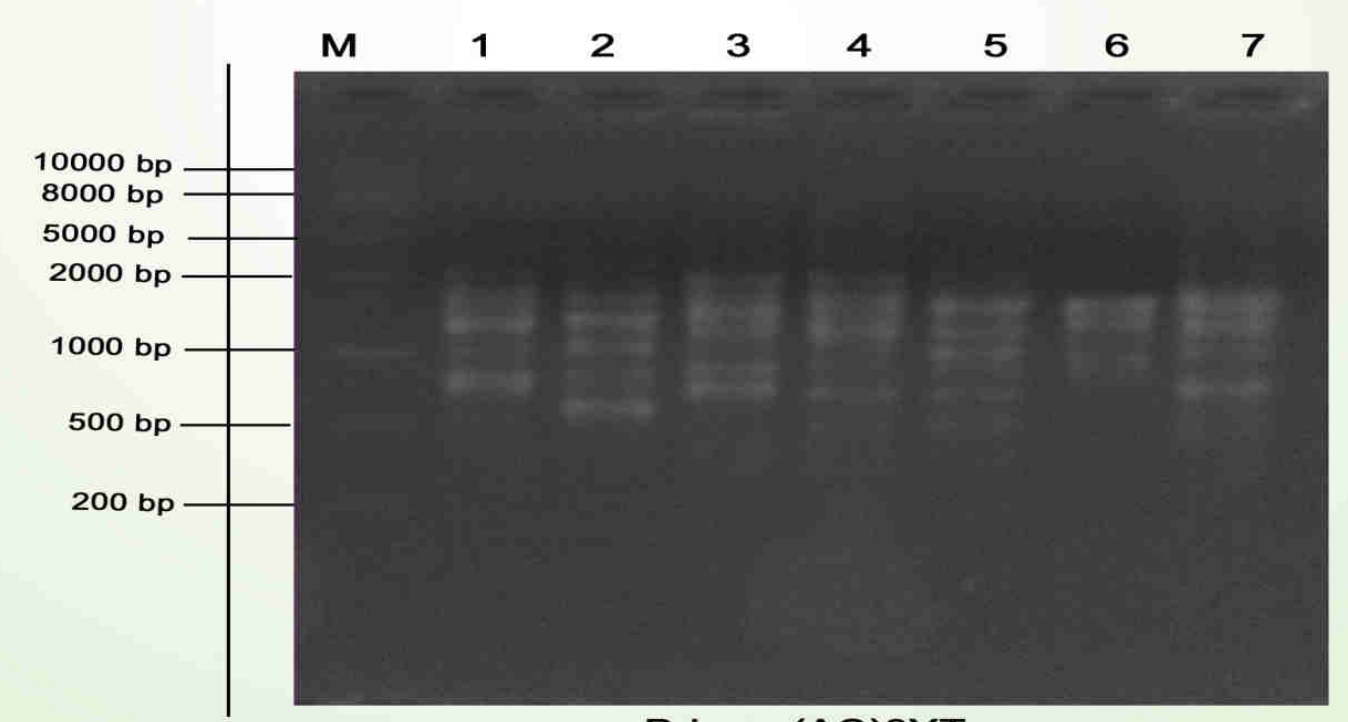

Primer (AC)8YT

M - 1 kb DNA Ladder,
1 - Wardha
2 - Lonar
3 - Washim
4 - Nashik
5 - Ahmadnagar
6 - Rahuri
7 - Pune

Plate 3: ISSR banding pattern of Primer $(C A)_{8} R Y$ and $(A C)_{8} Y T$ 